\title{
UJI EFEKTIVITAS REBUSAN BELIMBING WULUH (Averrhoa bilimbi) SEBAGAI PENGAWET ALAMI PADA IKAN TERI JENGKI (Stolephorus heterolobus) ASIN KERING
}

\author{
Lilla Puji Lestari' ${ }^{1}$, Evy Ratnasari Ekawati²) \\ ${ }^{1), 2)}$ Dosen Fakultas Ilmu Kesehatan, Universitas Maarif Hasyim Latif Sidoarjo \\ Email : lillafikesumaha@gmail.com
}

\begin{abstract}
This study aims to look at the effect of the boiling water treatment by dosage variation star fruit and storage of dried salted anchovy dungarees from microbiological aspects. This research used experimental laboratories methods, using factorial RAL. The results showed that the higher the dosage of boiling water star fruit significantly affect the number of bacteria $(p<0,05)$. While for the treatment of storage time of 6,12 and 24 hours significantly effect of bacterial growth $(\mathrm{p}<0,05)$.
\end{abstract}

Keyword: Averrhoa bilimbi, Stolephorus heterolobus, Natural preservatives

\section{PENDAHULUAN}

Protein ikan sangat diperlukan manusia, hal ini karena selain mudah dicerna, juga mengandung asam amino dengan struktur yang hamper sama dengan asam amino dalam tubuh manusia. Kandungan protein dan air pada ikan cukup tinggi, sehingga ikan termasuk komoditi yang mudah rusak dan busuk. Setelah dipanen, setiap spesies ikan mengalami penurunan mutu biologi, fisik, kesegaran dan nilai gizi dari ikan. Ikan memiliki kandungan lemak yang rendah, sehingga ikan sering digunakan sebagai pengganti daging yang umumnya mengandung kolesterol dalam jumlah banyak (Pakaya, et al. 2014).
Ikan teri merupakan salah satu jenis ikan yang banyak terdapat di perairan laut Indonesia. Ikan ini banyak ditangkap oleh nelayan, karena memiliki arti penting sebagai bahan makanan yang dapat dimanfaatkan sebagai ikan segar maupun ikan kering. Sumber daya ikan teri yang cukup potensial ini merupakan suatu peluang untuk mengembagan usaha ikan teri kering yang telah banyak dikerjakan oleh pengolahan tradisional (Pakaya, et al. 2014).

Ikan teri merupakan salah satu makanan yang biasa diawetkan dengan cara diasinkan dan dikeringkan. Ikn teri banyak dikonsumsi oleh kalangan menengah ke bawah ternyata merupakan salah satu sumber kalsium terbaik untuk mencegah pengeroposan tulang (Amrullah, 
2012). Menurut Hendradi (2009) ikan teri merupakan sumber kalsium yang tahan dan tidak mudah larut dalam air. Ikan teri sangat baik sebagai sumber kalsium yang murah dan mudah didapat. Menurut Astawan (2008) ikan teri sangat tinggi kandungan proteinnya, yaitu $42 \mathrm{~g} / 100 \mathrm{~g}$ teri kering asin. Sumbangan zat gizi yang sangat berarti dari ikan teri adalah mineral, kalsium, fosfor dan zat besi.

Pengawetan ikan teri dengan cara penggaraman terdiri dari dua proses, yaitu proses penggaraman dan proses pengeringan. Ikan yang mengalami proses penggaraman akan menjadi lebih awet karena garam yang terdapat pada ikan kering dapat menghambat atau membunuh mikroba penyebab pembusukan ikan. Proses pengeringan ikan teri asin akan semakin menambah penurunan kadar air dalam tubuh ikan, sekaligus menjadi factor penghambat pertumbuhan mikroba (Afrianto dan Liviawati, 2010)..

Belimbing wuluh (Averrhoa bilimbi) merupakan tanamana buah-buahan yang mempunyai rasa asam yang sering digunakan sebagai pengawet ikan, daging, makanan ataupun sebagai bumbu sayuran. Belimbing wuluh juga telah banyak digunakan masyarakat sebagai obat batuk (Salsa, et al, 2004). Berbagai khasiat yang dimiliki oleh belimbing wuluh (Averrhoa bilimbi) tersebut disebabkan karena tumbuhan ini memiliki banyak sekali kandungan senyawa antara lain saponin, flavonoid dan polifenol (mursito, etal., 2004).

Terkit hal tersebut di atas, penulis terdorong untuk melakukan penelitian mengenai manfaat pemberian rebusan belimbing wuluh (Averrhoa bilimbi) dengan variasi dosis dan waktu terhadap pengawetan ikan teri jengki asin kering.

\section{METODOLOGI PENELITIAN}

Penelitian ini merupakan penelitian eksperimen laboratorium. Untuk mengetahui pengaruh dosis dan lama penyimpanan digunakan Rancangan Acak Lengkap (RAL) faktorial dengan 3 kali ulangan.

\section{Waktu dan Tempat Penelitian}

Penelitian ini telah dilaksanakan selama 4 bulan, dimulai bulan September sampai dengan bulan Desember 2016. Penelitian dilakukan di Laboratorium Kimia Analisa Makanan dan Minuman, Fakultas Ilmu Kesehatan Universitas Maarif Hasyim Latif Sidoarjo

\section{Alat dan Bahan Penelitian}

Kompor, panci, ember plastik, plastik, pinset, pipet ukur, beaker glass, cawan petri, colony counter, mikro pipet $1000 \mu$ l, blue tip, PZ steril, MHA

\section{Prosedur}

Konsentrasi rebusan belimbing wuluh yang digunakan adalah 60\%, $80 \%$ dan $100 \%$. Sedangkan lama penyimpanan yang dilakukan adalah 6 jam, 12 jam dan 24 jam. Parameter uji mikrobiologi yang dilakukan adalah Total Plate Count (TPC).

\section{HASIL DAN PEMBAHASAN}

\section{Hasil}

Hasil Total Plate Count (TPC) bakteri pada ikan teri jengki (Stolephorus heterolobus) asin kering yang direndam dalam berbagai variasi dosis rebusan 
belimbing wuluh (Averrhoa bilimbi) dan

disajikan pada Tabel 1.

pada berbagai waktu penyimpanan

Tabel 1. Jumlah Bakteri pada Ikan Teri Jengki Asi Kering pada Perlakuan dengan Variasi Dosis dan Waktu Penyimpanan

\begin{tabular}{cccccc}
\hline \multirow{2}{*}{$\begin{array}{c}\text { Dosis } \\
(\%)\end{array}$} & $\begin{array}{c}\text { Waktu } \\
\text { Penyimpanan } \\
(\mathbf{j a m})\end{array}$ & \multicolumn{4}{c}{ Hasil TPC (koloni/gram) } \\
\cline { 2 - 6 } & 6 & $6,2 \times 10^{4}$ & $6,0 \times 10^{4}$ & $6,2 \times 10^{4}$ & $6,1 \times 10^{4}$ \\
\hline \multirow{3}{*}{60} & 12 & $4,4 \times 10^{4}$ & $4,9 \times 10^{4}$ & $4,2 \times 10^{4}$ & $4,5 \times 10^{4}$ \\
\cline { 2 - 6 } & 24 & $3,4 \times 10^{4}$ & $4,4 \times 10^{4}$ & $4,0 \times 10^{4}$ & $3,9 \times 10^{4}$ \\
\cline { 2 - 6 } & 6 & $5,2 \times 10^{4}$ & $5,8 \times 10^{4}$ & $5,4 \times 10^{4}$ & $5,5 \times 10^{4}$ \\
\hline \multirow{3}{*}{80} & 12 & $4,4 \times 10^{4}$ & $3,5 \times 10^{4}$ & $4,0 \times 10^{4}$ & $4,0 \times 10^{4}$ \\
\cline { 2 - 6 } & 24 & $3,3 \times 10^{4}$ & $3,0 \times 10^{4}$ & $3,3 \times 10^{4}$ & $3,2 \times 10^{4}$ \\
\hline \multirow{2}{*}{100} & 6 & $4,0 \times 10^{4}$ & $3,9 \times 10^{4}$ & $3,5 \times 10^{4}$ & $3,8 \times 10^{4}$ \\
\cline { 2 - 6 } & 12 & $3,2 \times 10^{4}$ & $3,2 \times 10^{4}$ & $3,3 \times 10^{4}$ & $3,2 \times 10^{4}$ \\
\cline { 2 - 6 } & 24 & $2,5 \times 10^{4}$ & $2,0 \times 10^{4}$ & $2,4 \times 10^{4}$ & $2,3 \times 10^{4}$ \\
\hline
\end{tabular}

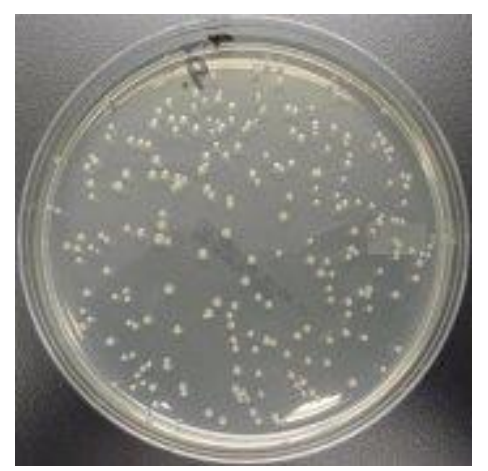

Gambar 1. Koloni bakteri pada teri jengki asin kering yang ditumbuhkan pada MHA

Pada air rebusan belimbing wuluh dosis $60 \%$ dengan masa penyimpanan 6 jam jumlah koloni bakteri yang tumbuh sebanyak 6,1 x $10^{4}$ koloni/gram sampel. Pada masa penyimpanan 12 jam jumlah koloni bakteri yang tumbuh sebanyak 4,5 x $10^{4}$ koloni/gram sampel dan pada masa penyimpanan 24 jam jumlah koloni bakteri yang tumbuh sebanyak 3,9 x $10^{4}$ koloni/gram sampel. Pada air rebusan belimbing wuluh dosis $80 \%$ dengan masa penyimpanan 6 jam jumlah koloni bakteri yang tumbuh $5,5 \times 10^{4}$ koloni/gram sampel, penyimpanan 12 jam jumlah bakteri 4,0 × $10^{4}$ koloni/gram sampel dan pada penyimpanan 24 jam jumlah koloni bakteri 3,2 x $10^{4}$ koloni/gram sampel. Pada air rebusan belimbing wuluh dosis $100 \%$ dengan lama penyimpanan 6 jam, jumlah bakteri $3,8 \times 10^{4}$ koloni/gram sampel, penyimpanan 12 jam jumlah bakteri 3,2 x $10^{4}$ koloni/gram sampel dan penyimpanan 24 jam jumlah bakteri $2,3 \times 10^{4} \mathrm{koloni} /$ gram sampel.

Jumlah bakteri dari 6 jam, 12 jam sampai 24 jam masa penyimpanan mengalami penurunan baik pada dosis $60 \%, 80 \%$ dan $100 \%$ air rebusan belimbing wuluh. Jika dibandingkan dengan standar mutu ikan teri asin kering (SNI 01-2708- 
1992) yang menyebutkanbahwa jumlah bakteri (TPC) maksimal 1 x $10^{5}$ koloni/gram sampel, menunjukkan bahwa jumlah bakteri yang tumbuh pada hasil penelitian ini pada air rebusan belimbing wuluh dosis $60 \%, 80 \%$ dan $100 \%$ dengan lama penyimpanan 6 jam, 12 jam dan 24 jam semuanya berada di bawah batas maksimalyang dipersyaratkan.

Semakin besar dosis air rebusan belimbing wuluh semakin berpengaruh nyata terhadap pertumbuhan bakteri $(\mathrm{p}<0,05)$, artinya semakin besar dosis air rebusan belimbing wuluh yang dipergunakan maka akan semakin kecil pertumbuhan bakteri. Untuk perlakuan lama penyimpanan ikan teri jengki asin kering yang telah direndam dalam air rebusan belimbing wuluh berpengaruh nyata terhadap pertumbuhan bakteri $(\mathrm{p}<0,05)$, artinya semakin lama waktu penyimpanan ikan teri jengki kering asin yang telah direndak air rebusan belimbing wuluh, maka akan semakin kecil pertumbuhan bakteri.

\section{Pembahasan}

Belimbing wuluh sejenis tanaman yang mengandung senyawa-senyawa yang berfungsi sebagai antimikroba sehingga secara langsung dapat menghambat pertumbuhan mikroba. Zat asam pada belimbing wuluh dapat membuat metabolism bakteri menjadi terganggu. Terganggunya metabolism ini disebabkan oleh terjadinya pertukaran ion asam $\left(\mathrm{H}^{+}\right)$ dari lingkungan dengan tubuh bakteri. Dinding bakteri bersifat permeable dengan komponen kimiawi seperti komponen lipid dan protein, namun sifat tersebut akan hilang jika terdapat perbedaan jumlah ion $\mathrm{H}$ di dalam dan di luar tubuh sel bakteri, sehingga mengakibatkan membrane sel bakteri menjadi asam. Kondisi asam membuat DNA tidak melakukan proses metabolism karena membutuhkan suasana yang netral (Pakaya, et al, 2014).

Menurut Afrianto dan Liviawaty (2010), membrane sitoplasma bakteri akan bersifat impermeable terhadap ion hidrogen dan ion hidroksil dan senyawasenyawa utama dari sel, seperti DNA dan ATP membutuhkan kondisi netral untuk bekerja. Kondisi ini membuat banyak bakteri yang tidak bermetabolisme sehingga tidak terjadi pertumbuhan bakteri dan berdampak pada menurunnya jumlah koloni seiring dengan lama penyimpanan.

Sejalan dengan Pelczar dan Chan (1988), mekanisme kerja antimikroba dapat terjadi mealui lima cara, yaitu hambatan sintesis dinding sel, perubahan permeabilitas sel, perubahan molekul dan asam nukleat, penghambatan kerja enzim, dan hambatan sintesis asam nukleat dan protein.

\section{KESIMPULAN}

Dari penelitian yang telah dilakukan dapat disimpulkan bahwa air rebusan belimbing wuluh (Averrhoa bilimbi) dapat dimanfaatkan sebagai pengawet alami pada ikan teri jengki (Stolephorus heterolobus).

\section{UCAPAN TERIMAKASIH}

Penulis mengucapkan terimakasih yang tak terhingga kepada tim dan semua pihak yang telah banyak membantu hingga penelitian ini selesai. 


\section{DAFTAR PUSTAKA}

Afrianto, E. dan E. Liviawaty. 2010. Pengawetan dan Pengolahan Ikan. Kanisius. Yogyakarta.

Amrullah, F. 2012. Kandungan Protein dan Kalsium (Ca) pada Ikan Teri Asin Hasil Pengasinan Menggunakan Abu Pelepah Kelapa. Naskah Publikasi Ilmiah. FKIP. Univ. Muhammadiyah Surakarta.

Astawan, Made. 2008. Sehat dengan Hidangan Hewani. Swadaya. Jakarta.

Hendradi. 2009. Ikan Teri Cegah Osteoporosis.

http://www.gizi.net/cgi-

bin/berita/fullnews.cgi?newsid10763

88924,5402. Diakses September 2016.

Mursito in Andanarudin, A., Winarsih, S. dan Widayat M. 2004. Uji Efektivitas Dekok Bunga Belimbing Wuluh (Averrhoa bilimbi) sebagai Antimikroba Terhadap Bakteri Salmonella typhii secara in vitro. Jurnal Kedokteran Brawijaya. 20 (1) : 30-34.
Pakaya, Y.T., A.H., Olli dan S. Nursinar. 2014. Pemanfaatan Belimbing Wuluh Sebagai Pengawet Alami pada Ikan Teri Asin Kering. Jurnal Ilmiah Perikanan dan Kelautan. 2(2) : 9396.

Pelczar, M.J. dan E.C.S. Chan. 1988. Dasar-dasar Mikrobiologi 2. UI Press. Jakarta.

Salsa in Andanarudin, A., Winarsih, S. dan Widayat M. 2004. Uji Efektivitas Dekok Bunga Belimbing Wuluh (Averrhoa bilimbi) sebagai Antimikroba Terhadap Bakteri Salmonella typhii secara in vitro. Jurnal Kedokteran Brawijaya. 20 (1) : 30-34.

SNI 01-2708-1992. Standar Nasional Indonesia : Ikan Teri Asin Kering. Bimbingan dan Pengujian Mutu Hasil Perikanan. Ditjen Perikanan. Jakarta. 